\title{
1. PALEOGENE AND NEOGENE PLANKTONIC FORAMINIFERAL BIOSTRATIGRAPHY OF THE NEW JERSEY CONTINENTAL SLOPE: SITES 902, 903, AND 904 (LEG 150) ${ }^{1}$
}

\author{
Scott W. Snyder, ${ }^{2}$ Kenneth G. Miller, ${ }^{3}$ and Esfir Saperson ${ }^{4}$
}

\begin{abstract}
Holes 904A, 902D, 903C, and 903A provide a cross-slope transect of the New Jersey Margin that is well suited to address the basic objectives of Leg 150 of the Ocean Drilling Program. Planktonic foraminiferal biostratigraphy, most complete at Site 904, correlates well with other approaches to Leg 150 stratigraphy (e.g., Sr-isotope analyses), despite problems with reworking (upper Eocene strata) and poor preservation (upper Miocene and portions of middle Miocene strata). The biostratigraphic framework provided by planktonic foraminifers at Sites 902-904 also agrees with and supplements interpretations on a broader regional scale, such as shore-based studies on the New Jersey Coastal Plain. However, the most striking feature revealed by biostratigraphic analyses is how different these three sites are from one another, despite their geographic proximity. These differences reflect the complex oceanographic and depositional history of the New Jersey Margin and its localized responses to both regional and global phenomena.
\end{abstract}

\section{INTRODUCTION}

The New Jersey continental slope and rise were drilled during Ocean Drilling Program Leg 150 in order to investigate the timing and magnitude of past global sea-level changes, specifically as they are manifested in siliciclastic sequences along a passive margin. Of the boreholes originally proposed for Leg 150 (MAT1-9 on the continental shelf and MAT10-12 on the slope), only those on the continental slope (MAT10-12; Sites 902-904) were approved for drilling (Miller, Mountain, and Shipboard Scientific Party, 1994). One additional slope site (Site 906) and one rise site (Site 905) were subsequently approved and drilled.

Sites 902,903 , and 904 (Fig. 1) are the focus of this report because (1) they form a cross-slope transect well suited to address the basic objectives of Leg 150, and (2) they contain better preserved and stratigraphically more complete planktonic foraminiferal assemblages than Sites 905 and 906 . At the two latter sites, extensive portions of the stratigraphic section are barren of planktonic foraminifers. Most sediments in Hole 905A, drilled on the upper continental rise, are either barren, contain sparse assemblages that are not age-diagnostic, or yield stratigraphically mixed associations. Age-diagnostic assemblages are sporadic, and occur largely in the lower $150 \mathrm{~m}$ of the drilled section of Hole 905A (Shipboard Scientific Party, 1994a). Hole 906A, drilled in the thalweg of modern Berkeley Canyon, is largely barren of planktonic foraminifers, although sparse assemblages, often not age-diagnostic, occur sporadically throughout the section (Shipboard Scientific Party, 1994b). Even though Sites 902 and 903 contain barren intervals, sediments more consistently contain age-diagnostic planktonic foraminiferal assemblages. Site 904 , however, clearly yields the most complete foraminiferal record.

Because detailed correlation among the holes drilled during Leg 150 will depend largely on siliceous and organic-walled microfossils,

'Mountain, G.S., Miller, K.G., Blum, P., Poag, C.W., and Twichell, D.C. (Eds.), 1996. Proc. ODP, Sci. Results, 150: College Station, TX (Ocean Drilling Program).

${ }^{2}$ Department of Geology, East Carolina University, Greenville, NC 27858, U.S.A. glsnyder@ecuvm.cis.ecu.edu

${ }^{3}$ Department of Geological Sciences, Rutgers University, Piscataway, NJ 08855 ; and Lamont-Doherty Earth Observatory, Columbia University, Palisades, NY 10962 , U.S.A.

${ }^{4} 69$ Grand Boulevard, Emerson, NY 07630, U.S.A. analyses of planktonic foraminifers are best focused on those sites where established biozonations based on calcareous microfossils can be directly related to the stratigraphic occurrences of siliceous and organic-walled taxa. Hence, we limit our discussions to Sites 902, 903, and 904.

\section{METHODS}

Results presented here are based on a combination of shipboard and shore-based sample analyses. Shipboard samples, mostly from

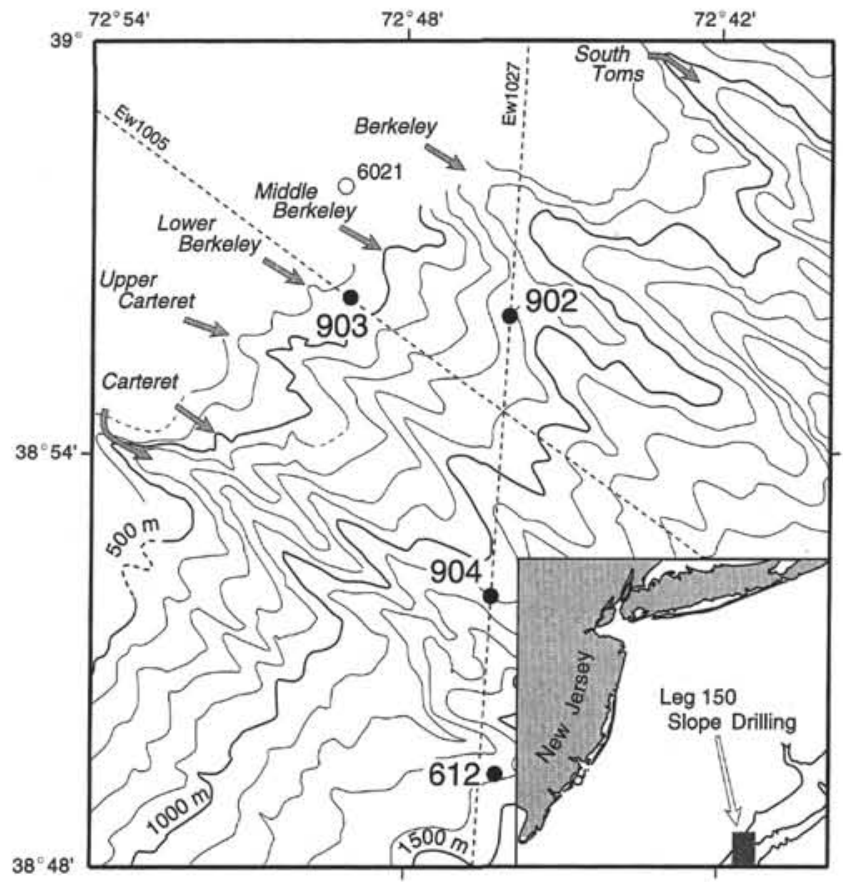

Figure 1. Locality map showing modern submarine canyons; ODP Sites 902 , 903, and 904; DSDP Site 612 (Leg 95); and tracks of seismic lines taken on the Maurice Ewing. 
core-catchers, of approximately $20 \mathrm{~cm}^{3}$ were soaked in a $3 \%$ solution of $\mathrm{H}_{2} \mathrm{O}_{2}$ and then heated in a $1 \%$ Calgon solution before being washed on a \#230 U.S. Standard Sieve (63- $\mu \mathrm{m}$ mesh). Although samples were estimated to be of similar volume, there was not sufficient time to precisely determine sample size. In addition, some samples could not be entirely disaggregated in the limited time available for shipboard processing, and the percentage of the bulk sample actually examined varied accordingly.

Shore-based analyses began by oven-drying bulk sediment samples at $45^{\circ} \mathrm{C}$ for $24 \mathrm{hr}$. Each dried sample was then weighed on a Sartorius B-120-S balance, transferred to a $1000-\mathrm{mL}$ beaker and immersed in approximately $250 \mathrm{~mL}$ of a $3 \% \mathrm{H}_{2} \mathrm{O}_{2}$ solution. After soaking for $24 \mathrm{hr}$ at $45^{\circ} \mathrm{C}$, the sample- $\mathrm{H}_{2} \mathrm{O}_{2}$ mixture was heated for $15 \mathrm{~min}$ and gently washed over a \#230 U.S. Standard Sieve (63- $\mu \mathrm{m}$ mesh). If the clay-silt fraction was not entirely disaggregated, the soaking, heating, and sieving procedures were repeated. The final wash utilized a \#18 U.S. Standard Sieve (1-mm mesh) to separate coarser material, if present, from the sand fraction concentrated on the $\$ 230$ sieve. Samples were then oven-dried at $45^{\circ} \mathrm{C}$, and both sand and coarse fractions, if present, were weighed and transferred to labeled vials for subsequent analysis.

The procedures outlined above permit the absolute number of planktonic foraminiferal specimens per gram (dry weight) of sediment to be estimated. Although these abundances were calculated only for samples from Hole 904A (Snyder, this volume), samples from other sites were processed so that abundance data could be calculated, if desired, at a later date.

The $>150-\mu \mathrm{m}$ fraction was routinely examined for planktonic foraminifers, and the 63- to $150-\mu \mathrm{m}$ fraction scanned for small specimens representing taxa that might otherwise have been missed. Biostratigraphic interpretations presented here were based on the analysis of 486 samples. For each of the four holes examined during this study, the numbers of shipboard and shore-based samples analyzed were as follows: Hole 902D-29 and 23; Hole 903A-70 and 14; Hole 903C-15 and 36; and Hole 904A-25 and 274.

For the Eocene section, we applied the tropical planktonic foraminiferal zonal terminology of Berggren and Miller (1988) and the taxonomic base of Toumarkine and Luterbacher (1985), modified in a few instances by concepts from Stainforth et al. (1975). For the Oligocene and Neogene section, we applied the planktonic foraminiferal zonal terminology of Blow $(1969,1979)$ and elements of the taxonomic base of Bolli and Saunders (1985), Kennett and Srinivasan (1983), and Stainforth et al. (1975). Sediments recovered from Sites 902,903 , and 904 often do not contain the key species used to define planktonic foraminiferal biozones. In the absence of nominate taxa, secondary species whose relative stratigraphic ranges have been extrapolated from other studies were used as proxies to make zonal assignments. Hence, the boundaries presented here often represent chronozones based on species other than those used to define the biozones in standard zonal schemes.

In addition, selected biostratigraphic events, namely the lowest occurrence (LO) and/or highest occurrence (HO) of key planktonic foraminiferal species and subspecies, were related to biochronology. The ages of these selected biostratigraphic events were drawn from publications by Berggren et al. (1985a, 1985b, 1985c, 1995). Publications from 1985 are referenced to be consistent with shipboard correlations, whereas the 1995 publication is referenced to provide calibration to the latest revisions of the time scale. The most up-to-date information on the stratigraphic ranges of key taxa (e.g., Berggren et al., 1995) was integrated, where appropriate, in making chronozonal assignments. Hence, our chronozones do not always reflect precisely the same ranges reported in established zonal schemes. The ages of those biostratigraphic events relevant to our study are summarized in Table 1.
Table 1. Biostratigraphic events (lowest and highest occurrences of selected taxa) used to interpret the foraminiferal biostratigraphy of Leg 150.

\begin{tabular}{|c|c|c|}
\hline Taxon & LO (Ma) & $\mathrm{HO}(\mathrm{Ma})$ \\
\hline Globorotalia cibaoensis & $6.7^{*}$ & \\
\hline Neogloboquadrina humerosa & $7.5^{* *}$ & \\
\hline Neogloboquadrina acostaensis & 10.9 & \\
\hline Globorotalia mayeri & & 11.4 \\
\hline Globigerina nepenthes & 11.8 & \\
\hline Globorotalia fohsi robusta & & 11.9 \\
\hline Globorotalia fohsi robusta & 12.3 & \\
\hline Globorotalia fohsi fohsi & 12.7 & \\
\hline Globorotalia fohsi peripheroronda & & 14.6 \\
\hline Globorotalia fohsi peripheroacuta & 14.8 & \\
\hline Orbulina suturalis & $15.2 * *$ & \\
\hline Globorotalia miozea & $16.8 * *$ & \\
\hline Catapsydrax dissimilis & & 17.6 \\
\hline Globorotalia scitula praescitula & 18.5 & \\
\hline Globigerinatella insueta & 18.8 & \\
\hline Globigerinoides altiaperturus & 20.5 & \\
\hline Globorotalia kugleri & & 21.5 \\
\hline Globoquadrina dehiscens & 23.2 & \\
\hline Globorotalia kugleri & 23.8 & \\
\hline Paragloborotalia opima opima & 30.6 & \\
\hline Hantkenina alabamensis & & 33.7 \\
\hline Turborotalia cerroazulensis cerroazulensis & & 33.8 \\
\hline Globigerinatheka index & & 34.3 \\
\hline Turborotalia cerroazulensis cunialensis & 35.2 & \\
\hline Turborotalia cerroazulensis pomeroli & & 35.3 \\
\hline Subbotina linaperta & & 37.7 \\
\hline Porticulosphaera semiinvoluta & 38.4 & \\
\hline Acarinina primitiva & & 39.0 \\
\hline Turborotalia cerroazulensis frontosa & & 39.5 \\
\hline Acarinina bullbrooki & & 40.5 \\
\hline Turborotalia cerroazulensis pomeroli & 42.4 & \\
\hline Globigerinatheka index & 42.9 & \\
\hline Morozovella lehneri & 43.5 & \\
\hline Morozovella aragonensis & & 43.6 \\
\hline Turborotalia cerroazulensis possagnoensis & 46.0 & \\
\hline
\end{tabular}

Note: Biochronology is from Berggren et al. (1995) unless otherwise noted (*W.A. Berggren, pers. comm., 1993; **Berggren et al., 1985c).

\section{RESULTS}

The following discussions address Sites 902-904 in order of decreasing water depth, progressing upslope from Site $904(1129 \mathrm{~m})$ to Site 902 ( $811 \mathrm{~m}$ ) to Site 903 (444 m) (Fig. 1). In addition to the logic of tracing the cross-slope transect in an orderly fashion, this approach permits the discussion to begin with Site 904 which, because it contains the most complete planktonic foraminiferal record, can serve as a reference section for the other sites.

\section{Site 904}

\section{Hole 904 A}

The Eocene section at Site 904 presents an interesting dilemma to biostratigraphic interpretation of the planktonic foraminifers. Extensive reworking of middle Eocene taxa upward into upper Eocene sediments makes even chronozonal assignments difficult. The zonal and chronozonal boundaries in this section (summarized in Fig. 2, where the occurrences of reworked specimens are indicated by dotted lines upward from interpreted $\mathrm{HO}$ datums) are often inferred based on the highest common and consistent occurrence of diagnostic taxa in conjunction with changes in the quality of preservation. These criteria are interpretive so zonal and chronozonal assignments must be viewed as tentative. Similar reworking of middle Eocene faunas along the mid-Atlantic margin of the United States has been noted by Poag and Low (1987), Miller et al. (1991), and Poag and Aubry (1995), whereas Macleod et al. (1990) reported no evidence of such allochthonous assemblages. Results from Site 904 suggest that such reworking was extensive. 


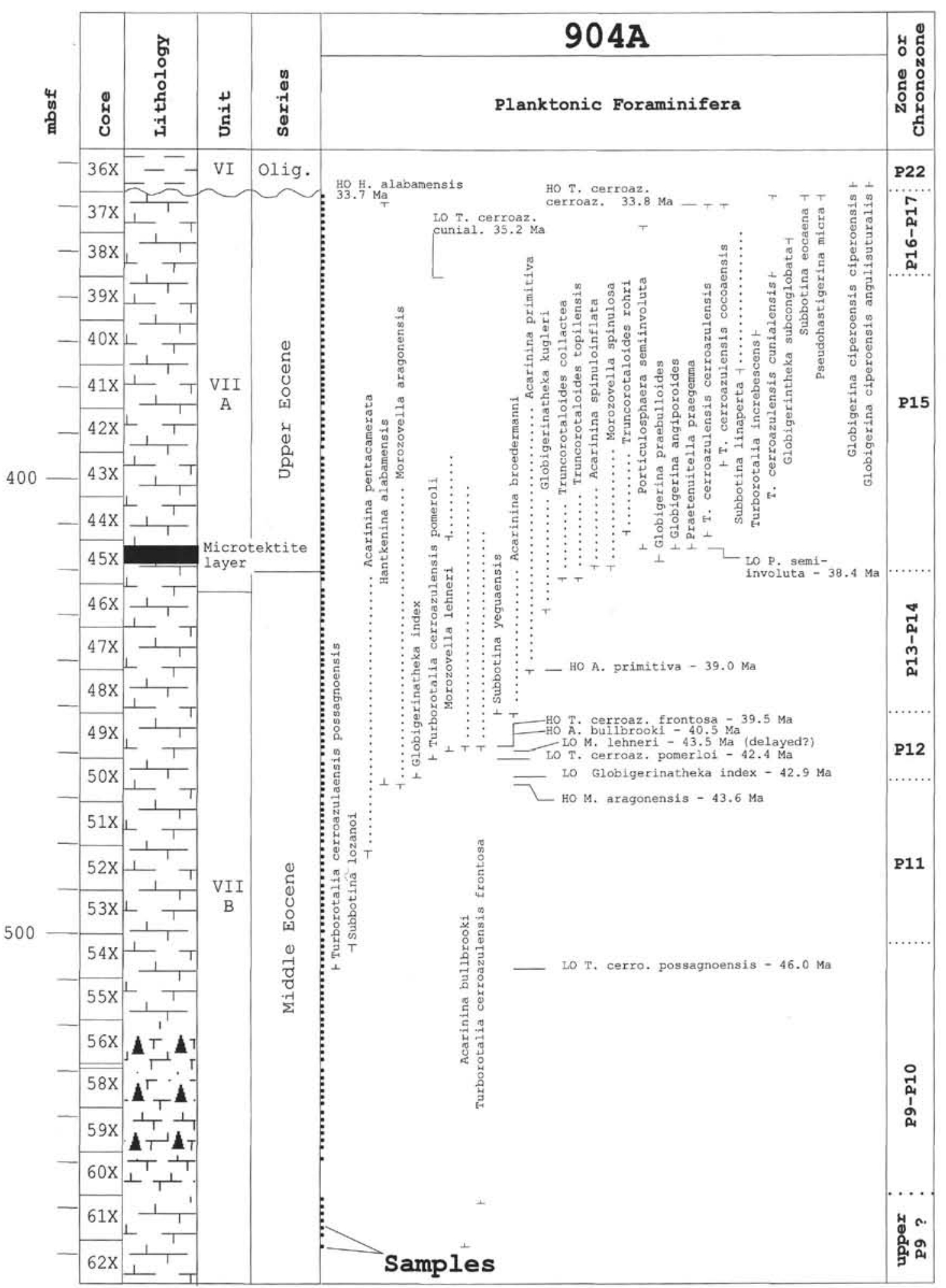

Figure 2. Planktonic foraminiferal biostratigraphy of the Eocene section, Hole 904A. Chronology of selected highest and lowest occurrences is from Berggren et al. (1995). Dotted lines above highest occurrence datums indicate presence of specimens interpreted to be reworked. (HO $=$ highest occurrence, LO $=$ lowest occurrence, $\mathrm{mbsf}=$ meters below seafloor.) 
The Eocene section extends upward from Sample 150-904A$62 \mathrm{X}-1,8-10 \mathrm{~cm}$, at $567.1 \mathrm{mbsf}$, to $904 \mathrm{~A}-37 \mathrm{X}-2,39-41 \mathrm{~cm}$, at 338.4 mbsf (Fig. 2). The lower portion of this section, below Sample 150$904 \mathrm{~A}-53 \mathrm{X}-1,39-41 \mathrm{~cm}$, at $490.6 \mathrm{mbsf}$, is characterized by erratic abundances of planktonic foraminifers (Snyder, this volume) and correspondingly variable preservation. Even in those samples with numerous specimens, preservation is fair to poor. Preservation of planktonic foraminifers is even worse below Sample 150-904A-58X$1,39-41 \mathrm{~cm}$, at $529.8 \mathrm{mbsf}$, in the porcellanitic nannofossil chalks that characterize the lower portion of Hole 904A. This preservational trend is clearly reflected by the fine fraction that could not be disaggregated during sample processing, and mirrors the degree of diagenetic alteration and cementation. Above Section 150-904A-53X-1, processed Eocene samples contain no residual fines $>63 \mu \mathrm{m}$; from Sections 904A-53X-1 downward through 904A-56X-6, residual fines expressed as weight percent of the original sample average $2.9 \%$; and from 904A-58X-1 downward, residual fines account for an average $37.1 \%$ of the original sample.

As a consequence of the preservational characteristics outlined above, planktonic foraminiferal biostratigraphy below about 490 mbsf (Section 904A-53X-1) is imprecise. Assignment to undifferentiated Chronozones P9-P10 is based on an association of taxa that range through this interval (e.g., Morozovella quetra, $M$. aragonensis, M. spinulosa, Acarinina broedermanni, A. pentacamerata, A. primitiva, A. spinuloinflata, A. bullbrooki, and Subbotina lozanoi) as well as other longer-ranging Eocene species. Because the nominate taxa for Zones P9 and P10 (Berggren and Miller, 1988) are not present, and because poor preservation results in the sporadic occurrence of taxa that have been identified, the N9/N10 chronozonal boundary cannot be approximated reliably. Turborotalia cerrazulensis frontosa has its LO in upper Core 61X, whereas Acarinina bullbrooki has its LO in uppermost Core $62 \mathrm{X}$; we tentatively assign these cores to Chronozone P9 based on the LO of these taxa in Zone P9 elsewhere (see discussion of these taxa in Berggren and Miller, 1988). While this interpretation is supported by nannofossil assignment of these cores to the lower Eocene, these LOs may not represent the true LOs because of poor preservation.

The base of Chronozone P11 is approximated by the LO of Turborotalia cerroazulensis possagnoensis ( $48.4 \mathrm{Ma}$ [Berggren et al., 1985a], readjusted to $46.0 \mathrm{Ma}$ [Berggren et al., 1995]), at Sample 150-904A-54X-4, 40-42 cm. The HO of Subbotina lozanoi, which ranges only into mid Zone P10 according to Toumarkine and Luterbacher (1985), in Sample 150-904A-50X-1, 40-42 cm, may be the product of reworking.

The base of Zone P12 is marked by the $\mathrm{HO}$ of Morozovella aragonensis (Berggren and Miller, 1988) in Sample 150-904A-50X-4, 40-42 cm. The HO of $M$. aragonensis (46.0 Ma [Berggren et al., 1985a], readjusted to $43.6 \mathrm{Ma}$ [Berggren et al., 1995]) is followed in rather close succession by the LO of Globigerinatheka index $(45.0$ $\mathrm{Ma}$ [Berggren et al., 1985c], readjusted to $42.9 \mathrm{Ma}$ [Berggren et al., 1995]) in Sample 150-904A-50X-3, 40-42 cm, the LO of Turborotalia cerroazulensis pomeroli (44.7 Ma [Berggren et al, 1985a], readjusted to $42.4 \mathrm{Ma}$ [Berggren et al., 1995]) in 904A-49X-7, 40-42 cm, the LO of Morozovella lehneri (46.0 Ma [Berggren et al., 1985a], readjusted to $43.5 \mathrm{Ma}$ [Berggren et al., 1995]) in 904A-49X-6, 40-42 $\mathrm{cm}$ (delayed? or true LO missed due to preservational circumstances), and the $\mathrm{HO}$ of both Acarinina bullbrooki (43.0 Ma [Berggren et al., 1985a], readjusted to $40.5 \mathrm{Ma}$ [Berggren et al., 1995]) and Turborotalia cerroazulensis frontosa (42.0 Ma [Berggren et al., 1985a], readjusted to $39.5 \mathrm{Ma}$ [Berggren et al., 1995]) in 904A-49X-5, 40-42 $\mathrm{cm}$. The apparent reversal of some events and the coincidence of others that should be separated by as much as $1 \mathrm{~m}$.y. results from reworking and from biostratigraphic imprecision attributable to poor preservation.

The absence of Globigerapsis beckmanni, along with the lack of any secondary or tertiary marker species at Site 904, precludes the separation of Chronozones P13 and P14. The P14/P15 zonal boundary is placed just below the LO of Porticulosphaera semiinvoluta (41.3 Ma [Berggren et al., 1985a], readjusted to $38.4 \mathrm{Ma}$ [Berggren et al. 1995]) at the interpreted HOs of Morozovella spinuloinflata, Truncorotaloides topilensis, and T. collactea, all of which occur upsection where they are interpreted to be reworked. The HO of Truncorotaloides rohri, which should correspond to the HOs of the aforementioned species, is interpreted to lie higher, at Sample 150-904A$44 \mathrm{X}-6,39-41 \mathrm{~cm}$. Overlying sediments contain the LOs of ancillary species that do not occur below Zone P15 (e.g., Globigerina praebulloides and Praetenuitella praegemma). The P14/P15 zonal boundary is placed at Sample 150-904A-45X-5, 40-42 cm, $4.1 \mathrm{~m}$ below a tektite-bearing interval. The apparent reversals and delays of biostratigraphic events that approximate this zonal boundary are once again attributable to extensive reworking, the cause of which may be related to the impact that produced the overlying tektite layer (McHugh et al., this volume). The $\mathrm{HO}$ of Subbotina linaperta (about $40.6 \mathrm{Ma}$ [Berggren et al., 1985b], readjusted to 37.7 Ma [Berggren et al., 1995]) lies within Chronozone P15 at Sample 150-904A-41X-1, 40$42 \mathrm{~cm}$.

The nominate taxon for Zone P16 (Cribrohantkenina inflata) has not been identified at Site 904, but the base of its chronozone can be approximated by the LO of Turborotalia cerroazulensis cunialensis (Berggren and Miller, 1988; Poag and Aubry, 1995). Chronozones $\mathrm{P} 16$ and $\mathrm{P} 17$ cannot be differentiated reliably. Biostratigraphic events that occur within the P16-P17 chronozonal interval include: $\mathrm{LO}$ of $T$. cerroazulensis cunialensis (38.6 Ma [Berggren et al., 1985b], readjusted to 35.2 Ma [Berggren et al. 1995]) in Sample 150-904A-38X$4,39-41 \mathrm{~cm}, \mathrm{HO}$ of Globigerinatheka index (37.0 Ma [Berggren et al., 1985a], readjusted to $34.3 \mathrm{Ma}$ [Berggren et al. 1995]) in Sample 150-904A-38X-2, 41-43 cm, and the HOs of $T$. cerroazulensis cerroazulensis (36.6 Ma [Berggren et al., 1985a], readjusted to $33.8 \mathrm{Ma}$ [Berggren et al., 1995]) and Hantkenina alabamensis (36.6 Ma [Berggren et al., 1985a], readjusted to $33.7 \mathrm{Ma}$ [Berggren et al., 1995]) in Sample 150-904A-37X-2, 36-38 cm. The HOs of the latter two species may be truncated by erosion associated with the unconformity that caps the Eocene section.

The Oligocene-Miocene section extends from Sample 150-904A$37 \mathrm{X}-1,40-42 \mathrm{~cm}$, at $336.9 \mathrm{mbsf}$ upward to $904 \mathrm{~A}-12 \mathrm{H}-2,65 \mathrm{~cm}$, at $106.2 \mathrm{mbsf}$. A thin upper Oligocene section $(19.2 \mathrm{~m})$ is overlain by $212.1 \mathrm{~m}$ of Miocene. Lower Miocene planktonic foraminiferal biostratigraphy is good, that for the middle Miocene section somewhat less detailed, and that for the upper Miocene section limited to a few fossiliferous samples in Core 150-904A-19H overlain by $71.5 \mathrm{~m}$ of barren sediments. These sediments, assigned to the upper Miocene on the basis of other fossils, are disconformably overlain by Pleistocene muds. Biostratigraphic results vary directly with the abundance patterns of planktonic foraminifers through the Neogene portion of the section (Snyder, this volume). Details of the upper Oligocene-Miocene planktonic foraminiferal biostratigraphy discussed below are graphically summarized on Figure 3.

Upper Oligocene siliciclastic clays disconformably overlie upper Eocene chalks. Assignment to Chronozone P22 is based on the absence of characteristic lower to lower upper Oligocene taxa (e.g., Pseudohastigerina spp. and Paragloborotalia opima opima) in sediments that immediately overlie upper Eocene Chronozone P17, in combination with the presence of upper Oligocene indicators (most importantly, Globigerina ciperoensis ciperoensis and G. ciperoensis angulisuturalis). The LOs of both are in Sample 150-904A-36X-CC, whereas the $\mathrm{HO}$ of $G$. ciperoensis s.s. is in Sample 150-904A-35X-7, $39-41 \mathrm{~cm}$, and the HO of G. ciperoensis angulisuturalis is in Sample 904A-35X-3, 39-41 cm. The HO of Globigerina tripartita in Sample $150-904 \mathrm{~A}-35 \mathrm{X}-1,39-41 \mathrm{~cm}$, supports this chronozonal assignment.

The base of Zone N4 (= the base of the Miocene) is placed at the LO of Globorotalia kugleri, which occurs in Sample 150-904A-33XCC. Forms here assigned to $G$. kugleri possess distinctly recurved su- 


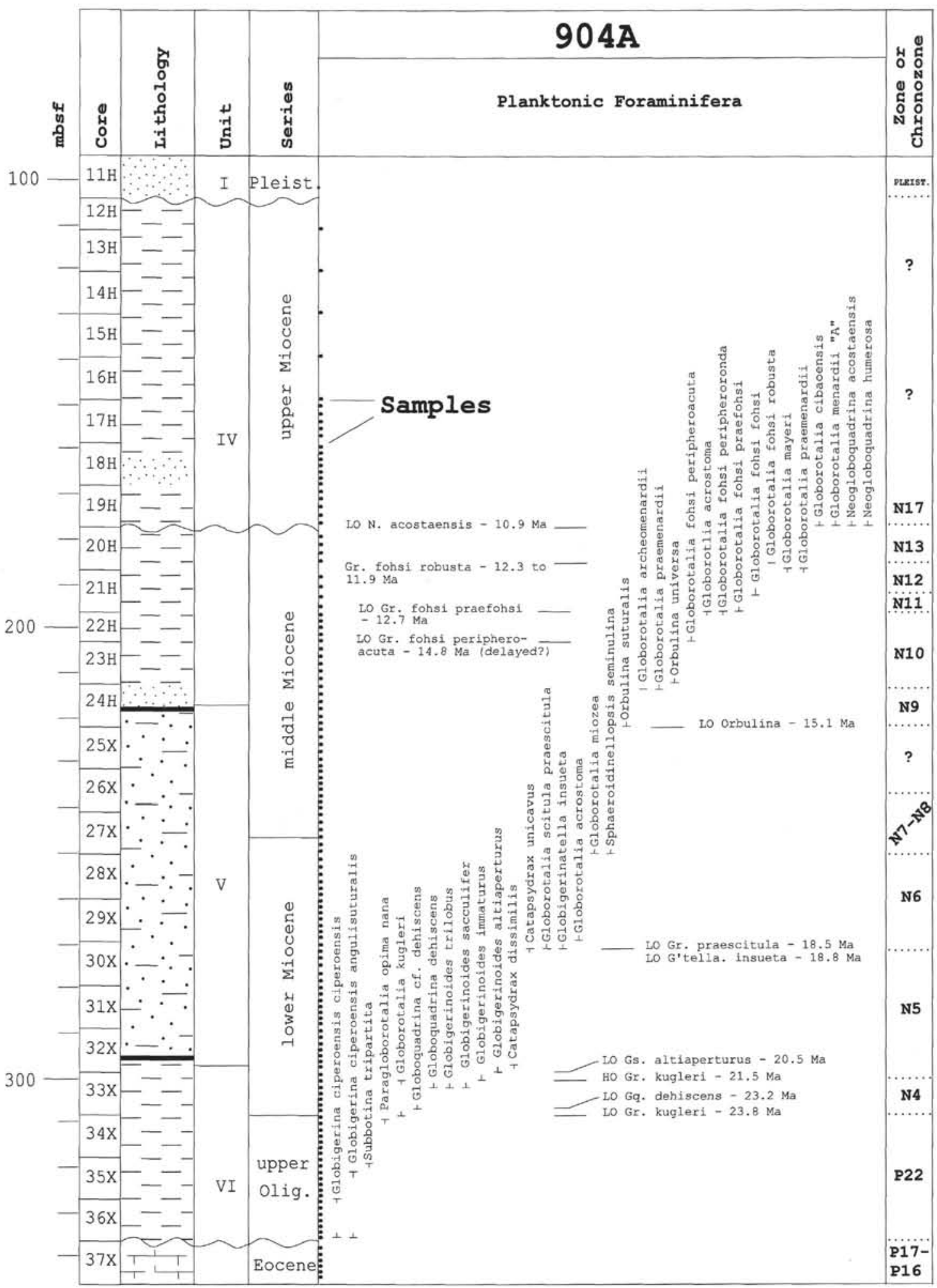

Figure 3. Planktonic foraminiferal biostratigraphy of the Oligocene-Miocene section, Hole 904A. Chronology of selected highest and lowest occurrences is from Berggren et al. (1995). 
tures (see Miller et al., 1989; Leckie et al., 1993), which help to distinguish them from $G$. pseudokugleri. The LO of G. kugleri corresponds to an age of $23.7 \mathrm{Ma}$ (Berggren et al., 1985a), readjusted to 23.8 Ma (Berggren et al., 1995). The LO of Globoquadrina dehiscens, indicative of an age of $23.2 \mathrm{Ma}$ (Berggren et al., 1985c, 1995), is in Sample 150-904A-33X-5, $110 \mathrm{~cm}$. The HO of Globorotalia kugleri (21.8 Ma [Berggren et al., 1985c], readjusted to $21.5 \mathrm{Ma}$ [Berggren et al., 1995]) is in Sample 150-904A-33X-2, 40-42 cm. Hence, Zone $\mathrm{N} 4 \mathrm{a}$ or $\mathrm{N} 4 \mathrm{~b}$, or at least significant parts of either, may be missing.

The HO of Globorotalia kugleri defines the N4/N5 zonal boundary, which also may be approximated at Site 904 by the LO of Globigerinoides trilobus (Sample 150-904A-33X-3, 40-42 cm), Gs. immaturus (Sample 150-904A-33X-2, 40-42 cm) and Gs. sacculifer (Sample 150-904A-33X-3, 40-42 cm). The LO of Globigerinoides altiaperturus (20.9 Ma [Berggren et al., 1985c], readjusted to 20.5 Ma [Berggren et al., 1995]) occurs in lowermost Chronozone N5 in Sample 150-904A-32X-CC. The HO of Catapsydrax dissimilis (Sample 150-904A-32X-5, 40-42 cm) is premature here, as it is in the Gulf of Mexico (Zhang et al., 1993). However, Catapsydrax unicavus occurs, albeit sporadically, upward to Sample 150-904A-30X$2,36-38 \mathrm{~cm}$, which coincides with the N5/N6 chronozonal boundary in Hole 904A.

The LO of Globorotalia scitula praescitula (17.7 Ma [Berggren et al., 1985c], readjusted to $18.5 \mathrm{Ma}$ [Berggren et al., 1995]) is at the same level as the LO of Globogerinatella insueta (18.8 Ma; Berggren et al., 1995), in Sample 150-904A-30X-2, 36-38 cm. This is similar to the relationship noted by Miller et al. (1989), who suggested that the LO of the former can be used as a proxy for the base of Chronozone N6. The LO of Globorotalia acrostoma occurs slightly higher in Sample 150-904A-27X-7, 75-76 cm.

The LO of Globorotalia miozea (16.8 Ma; Berggren et al., 1985c) and secondarily of Sphaeroidinellopsis seminulina are used to approximate the base of Chronozone N7. The LOs of both taxa are in Sample 150-904A-27X-CC. Use of the LO of G. miozea to approximate the N6/N7 chronozonal boundary is supported by its LO at Site 558 , which is just above the $\mathrm{HO}$ of Catapsydrax dissimilis (17.6 Ma; Berggren et al., 1985c) in earliest C5Cr, and by its LO at Site 563 just below the LO of Praeorbulina sicanus (16.6 Ma; Berggren et al., 1985c) within C5Cr (Miller et al., 1985). However, the LO of $P$. sicanus at Site 563 coincides with the LO of $P$. glomerosa immediately above the $\mathrm{HO}$ of $\mathrm{C}$. dissimilis, indicating an unconformity (Miller et al., 1985). Because the LO of G. miozea at Site 563 is within the $C$. dissimilis Zone (N6), its exact position within the zone cannot be determined because of the unconformity at the top of the zone. The LO of Sphaeroidinellopsis in lower Core 904A-27X at the same level as the LO of G. miozea is also similar to Site 563, where the LO of Spaheroidinellopsis is in C5Dn (uppermost N6). Although both nannofossil ranges (Aubry, this volume) and $\mathrm{Sr}$-isotope analyses (Miller et al., this volume) suggest the presence of Chronozone N8, specimens of $P$. sicanus have not yet been identified at Site 904, so Zones N7 and N8 cannot be differentiated on the basis of planktonic foraminifers.

The stratigraphic interval between Samples 150-904A-26X-7, $40-42 \mathrm{~cm}$, and $904 \mathrm{~A}-24 \mathrm{H}-5,40-42 \mathrm{~cm}$, is barren of planktonic foraminifers. Hence, no zonal assignments are possible.

The base of Zone N9 is placed at the LO of Orbulina in Sample $150-904 \mathrm{~A}-24 \mathrm{H}-5,40-42 \mathrm{~cm}$. This corresponds to the LO of $O$. suturalis (15.2 Ma; Berggren et al., 1985c), whereas the LO of $O$. universa is delayed until Sample 150-904A-23H-CC, probably as a result of preservational circumstances (see Chaisson and Leckie, 1993).

The base of Chronozone N10 is approximated by the LO of Globorotalia praemenardii in Sample 150-904A-24H-2, 40-42 cm. Although Globorotalia fohsi peripheroacuta (LO at 14.9 Ma; Berggren et al., 1985c) is present at Site 904, its LO is not until Sample $150-904 \mathrm{~A}-22 \mathrm{H}-\mathrm{CC}$. Because it is rare and it occurs sporadically, its
LO here may be significantly delayed ( $>2$ m.y.; Miller et al., this volume), possibly due to lack of preservation lower in the section.

The LO of Globorotalia fohsi praefohsi, in Sample 150-904A$21 \mathrm{H}-\mathrm{CC}$, is used to place the base of Zone N11. This does not agree with $\mathrm{Sr}$-isotope analyses, and again it may represent a delayed first appearance, albeit minor ( $<1 \mathrm{~m} . \mathrm{y}$.; Miller et al., this volume). The N11-N12 zonal boundary is placed at the LO of Globorotalia fohsi fohsi in Sample 150-904A-21H-4, 40-42 cm.

The presence of Globorotalia fohsi robusta in Sample 150-904A$20 \mathrm{H}-4,110-112 \mathrm{~cm}$, indicates upper Zone N12 (12.6 to $11.5 \mathrm{Ma}$ [Berggren et al., 1985c], readjusted to 12.3 to $11.9 \mathrm{Ma}$ [Berggren et al., 1995]). This disagrees with interpretations based on the highest occurrence of Globorotalia mayeri, which probably represents a truncated top at Site 904 . The HO of $G$. mayeri (11.4 Ma; Berggren et al., 1995), which under other circumstances might be interpreted to indicate Chronozone N14, occurs in Sample 150-904A-20H-CC, well below the $\mathrm{LO}$ of $G$. fohsi robusta.

Samples 150-904A-19H-CC and 904A-19H-3, 90-92 cm, contain specimens of taxa indicative of Chronozone N17. Diagnostic taxa include Globorotalia cibaoensis (LO at 6.7 Ma [W. Berggren, pers. comm., 1993; Chaisson and Leckie, 1993]), Gr. menardii "A," Neogloboquadrina acostaensis, and $N$. humerosa (LO at $7.5 \mathrm{Ma}$; Berggren et al., 1985c). This interpretation implies a disconformity below Core $19 \mathrm{H}$ and is not consistent with interpretations based on shipboard analyses of diatoms and dinoflagellates. However, nannofossil assignment to Zone NN10 (Aubry, this volume) is consistent with foraminiferal evidence. In addition, the Sr-isotope analyses indicate late middle Miocene ages for Cores $18 \mathrm{H}$ and $19 \mathrm{H}$. However, benthic foraminifers from these cores indicate that many but not all of the specimens have been transported and possibly reworked (Katz and Miller, this volume). The inversion of $\mathrm{Sr}$-isotope ages (e.g., 11.3 $\mathrm{Ma}$ in Core $20 \mathrm{H}$ and $12.9 \mathrm{Ma}$ in Core $19 \mathrm{H}$ ) is also suggestive of reworking (Miller et al., this volume). These unusual circumstances lend credence to the planktonic foraminiferal interpretation of Core $19 \mathrm{H}$ as upper Miocene Chronozone N17. Based on a series of papers that progressively refined Oligocene-Miocene $\mathrm{Sr}$-isotope stratigraphy (Miller et al., 1988, 1991; Hodell et al., 1991; Oslick et al., 1994), Miller et al. (this volume) interpreted the Oligocene to Miocene Srisotope stratigraphy of the New Jersey continental slope. In the Oligocene to lower Miocene section of Site 904, planktonic foraminiferal biostratigraphy corresponds closely with $\mathrm{Sr}$-isotope ages. In the middle Miocene, $\mathrm{Sr}$-isotope stratigraphy delineates an early middle Miocene unconformity not resolved by planktonic foraminiferal biostratigraphy and suggests the delayed LOs of at least two taxa. The discrepancy between planktonic foraminiferal biostratigraphy and Sr-isotope stratigraphy in Core $19 \mathrm{H}$ may be the result of reworking and resultant stratigraphic mixing of specimens measured for $\mathrm{Sr}$ isotopes.

\section{Site 902}

\section{Hole 902D}

Although four holes were drilled at Site 902, only Hole 902D extending to a total depth of 736.6 mbsf, penetrated below Pleistocene sediments. This hole penetrated into upper Eocene sediments, but a large portion of the thick Miocene section is barren of planktonic foraminifers. Because such a large portion of the section is barren, true LOs and HOs were rarely encountered. Hence, the graphic summary of Hole 902D (Fig. 4) does not attempt to plot LOs and HOs; instead, a dashed line depicts the entire stratigraphic range through which each taxon is represented. However, a continuous dashed line does not imply that a taxon is represented in all samples through its labeled interval of occurrence. Foraminifers are often scarce and occur sporadically, especially in Miocene sediments. Often Miocene biostratigraphy is based on assemblages composed of $<10$ specimens. Age-diagnostic taxa may be represented by a single specimen. Con- 


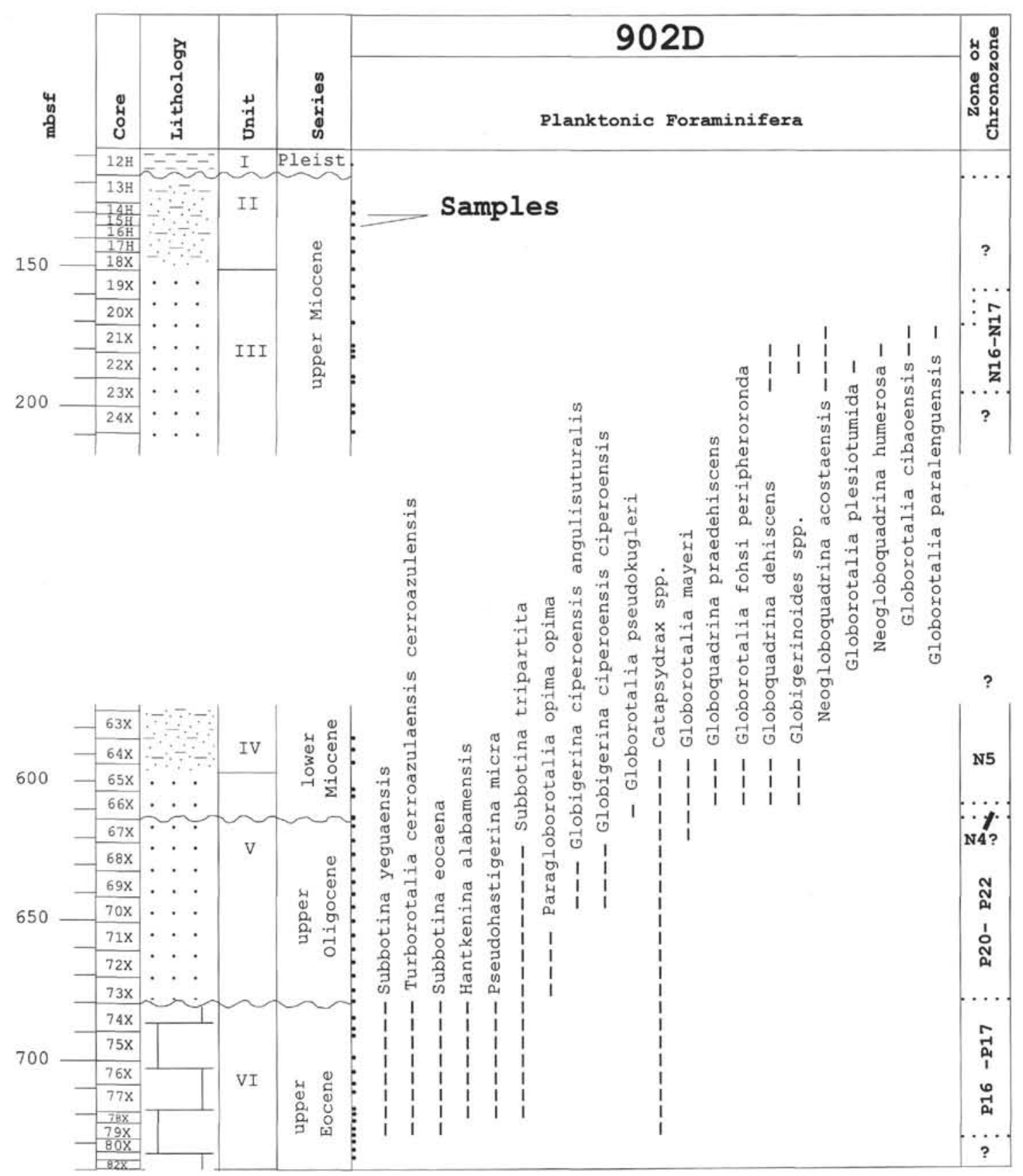

Figure 4. Planktonic foraminiferal biostratigraphy of Hole 902D. Dashed lines indicate entire stratigraphic range of taxa but do not imply that specimens occur in all samples within that range.

sequently, the zonal and chronozonal assignments and boundaries are tentative.

Eocene sediments at the very base of the section (Core 150-902D$82 \mathrm{X}$ ) were not available for planktonic foraminiferal analyses. The stratigraphically lowest sample examined (150-902D-81X-1, 10-12 $\mathrm{cm})$ contains an assemblage assignable to undifferentiated Chronozones P16-P17. This assemblage, which typifies samples upward through 150-902D-74X-2, 75-77 cm, includes Turborotalia cerroazulensis cerroazulensis, Hantkenina alabamensis, Pseudohastigerina micra, Subbotina yeguaensis, and S. eocaena, all of which disappear at the unconformity that caps the Eocene section. The presence of Subbotina tripartita and the absence of S. linaperta (HO at about $40.6 \mathrm{Ma}$ [Berggren et al., 1985b], readjusted to $37.7 \mathrm{Ma}$ [Berggren et al., 1995]) through these samples suggests that Zone P15 was not penetrated.

Sediments immediately overlying the unconformity truncating the upper Eocene section are assigned to undifferentiated Chronozones P21-P22. The lower portion of this Oligocene section (Samples 150-902D-74X-1, 92-94 cm, through 902D-71X-4, 24-26 cm) contains Paragloborotalia opima opima (LO at $32.7 \mathrm{Ma}$ [Berggren et al., 1985a], readjusted to $30.6 \mathrm{Ma}$ [Berggren et al., 1995]) and Subbotina tripartita, which persists upward through Sample 150-902D- 
67X-CC. Globigerina ciperoensis ciperoensis and G. ciperoensis angulisuturalis both first occur in Sample 150-902D-70X-3, 37-38 cm, and persist upward through 902D-67X-CC.

The base of the Miocene is placed at Sample 150-902D-66X-CC where Oligocene marker species disappear, to be replaced by an assemblage containing Globorotalia pseudokugleri, G. cf. G. kugleri, and $G$. mayeri among other longer-ranging species. This may represent a thin interval assignable to Zone N4. In Sample 150-902D-65X$\mathrm{CC}$, the association of Globoquadrina praedehiscens, G. dehiscens, Globorotalia fohsi peripheroronda, and common Globigerinoides spp. is interpreted to represent Chronozone N5, but may be as young as N6. Assignment to N5 is supported by a Sr-isotope age for Sample 902D-66X-5, 50-52 cm, of 23.2 Ma (Miller et al., this volume).

Sediments between Samples 150-902D-64X-5, 126-128 cm, and 902D-23X-1, 39-41 cm, are barren of planktonic foraminifers. No biostratigraphic interpretation is possible for this 400 -m-thick stratigraphic interval.

The interval from Samples 150-902D-23X-1, 39-41 cm, through 902D-21X-3, 117-122 cm, contains specimens of taxa indicative of Zones N16-N17. The assemblage includes Neogloboquadrina acostaensis, Globorotalia cibaoensis, G. plesiotumida, and G. paralenguensis. The occurrence of Neogloboquadrina humerosa in Sample $150-902 \mathrm{D}-21 \mathrm{X}-\mathrm{CC}$ might be used to approximate the N16/N17 zonal boundary. However, because this form occurs in only one sample and is represented by only a few specimens, these upper Miocene sediments are lumped into undifferentiated Zones N16-N17. The overlying Neogene section is again devoid of planktonic foraminifers. The next fossiliferous samples lie within the Pleistocene.

\section{Site 903}

Four holes were drilled at Site 903. The results discussed below represent the composite section recovered in two of them: $903 \mathrm{~A}$ and $903 \mathrm{C}$.

\section{Hole $903 C$}

The Eocene section in Hole 903C extends from its total depth of 1149.7 mbsf upward through Sample 903C-52R-3, 98-100 cm (Fig. 5). The unconformity that caps the Eocene occurs at the top of Core $52 \mathrm{R}$. As in Hole 902D, graphic summaries of the planktonic foraminiferal biostratigraphy (Figs. 5-7) do not plot LOs or HOs, but rather indicate stratigraphic ranges of individual taxa as dashed lines. Also as before, a continuous dashed line does not necessarily imply that a taxon is represented in all samples of the stratigraphic interval through which it is recorded.

Middle Eocene sediments assignable to Chronozones P13 and P14 occur from the bottom of the hole upward to Sample 150-903C57R-CC. The P13/P14 chronozonal boundary is approximated by the $\mathrm{HO}$ of Acarinina primitiva (40.6 Ma [Berggren et al., 1985a], readjusted to 39.0 Ma [Berggren et al., 1995]). Chronozone P14 extends upward to Section 903C-57R-CC, which marks the highest in situ occurrence of several middle Eocene indicator species (Acarinina spinuloinflata, Truncorotaloides spp., and Morozovella spinulosa). Although Berggren et al. recognized the $\mathrm{HO}$ of Acarinina bullbrooki near the base of Zone P13 (43.0 Ma [Berggren et al., 1985b], readjusted to $40.5 \mathrm{Ma}$ [Berggren et al., 1995]), this taxon persists upward through sediments interpreted as Chronozone P14 in Hole 903C (similar to the range suggested by Toumarkine and Luterbacher, 1985). It is possible that some of these specimens are reworked. Other middle Eocene markers occur in Sample 150-903C-57R-3, 20-22 $\mathrm{cm}$, but their reduced abundances and poorer preservation suggest reworking across the unconformity that separates middle from upper Eocene sediments. The reworking here is not as pervasive as that described for Hole 904A.

Chronozone P15 contains representatives of none of the aforementioned middle Eocene species. It is typified by assemblages that include specimens of Subbotina yeguaensis, S. tripartita, subspecies of Turoborotalia cerroazulensis, and Praetenuitella praegemma. The P15/P16 chronozonal boundary is approximated by the HO of Turborotalia cerroazulensis pomeroli (37.8 Ma [Berggren et al., 1985b], readjusted to $35.3 \mathrm{Ma}$ [Berggren et al., 1995]). Subbotina linaperta (HO in lower P15 at about $40.6 \mathrm{Ma}$ [Berggren et al., 1985b], readjusted to $37.7 \mathrm{Ma}$ [Berggren et al., 1995]) persists to the top of Chronozone P15 as interpreted here. Perhaps the HO of T. cerroazulensis pomeroli represents a truncated top, or perhaps reworking has introduced specimens of $S$. linaperta into higher portions of Chronozone P15. However, specimens exhibit no obvious signs of reworking. The P16/P17 chronozonal boundary is questionably placed at Sample 150-903C-53R-CC, near the LO of Turborotalia increbescens and the HO of Globigerinatheka index.

The unconformity at the top of the Eocene section is marked by the HOs of Subbotina eocaena, Turborotalia cerroazulensis cocoaensis, T. increbescens, and Pseudohastigerina micra. Hantkenina alabamensis disappears slightly lower, possibly due to lack of preservation immediately beneath the unconformity.

Oligocene sediments from Sample 150-903C-51R-CC upward through Core 44R are tentatively assigned to undifferentiated Chronozones P21-P22 (Fig. 6). This interval contains low diversity assemblages that often lack age-diagnostic taxa. Most samples include Paragloborotalia opima nana, Catapsydrax spp. and Globigerina venezuelana, all of which are long-ranging. Samples 150-903C-48R1, 36-38 cm, and 903C-47R-CC contain Globigerina ciperoensis ciperoensis. No diagnostic lower Oligocene taxa were encountered anywhere within the Oligocene section. $\mathrm{Sr}$-isotope analyses show that samples from Cores $44 \mathrm{R}$ through $42 \mathrm{R}$ are equivalent to Chronozone N4 (Miller et al., this volume), but planktonic foraminifers in this interval are not age-diagnostic.

Lower Miocene sediments assignable to Chronozones N5 to mid N6 are encountered in Sample 150-903C-41R-3, 7-9 cm, which contains a more diverse assemblage that includes Globorotalia mayeri, G. fohsi peripheroronda, Globigerinoides spp., Globoquadrina altispira globosa, and forms transitional from Paragloborotalia opima nana to Neogloboquadrina continuosa. The LO of Globigerinoides altiaperturus (20.9 Ma [Berggren et al., 1985c], readjusted to 20.5 Ma [Berggren et al., 1995]), often used as a proxy for the base of Zone N5, is in Sample 903C-39R-5, 26-28 cm. Globoquadrina dehiscens (LO at 23.2 Ma; Berggren et al., 1985c, 1995) first occurs in this same sample, probably because of lack of preservation in underlying samples which contain very few specimens.

Sediments above Sample 150-903C-39R-5, 26-28 cm, are barren of planktonic foraminifers, with the exception of an occasional sample that contains the odd specimen of a particularly dissolution-resistant species (e.g., Globorotalia miozea). Fossiliferous sediments with age-diagnostic assemblages are next encountered at Sample 903C$19 \mathrm{R}-\mathrm{CC}$ where longer ranging Miocene species occur with forms that indicate Chronozone $\mathrm{N} 11$ (Globorotalia archeomenardii and G. peripheroacuta, the LO of the latter indicating an age at least as young as $14.9 \mathrm{Ma}$ (Berggren et al., 1985c), readjusted to $14.8 \mathrm{Ma}$ (Berggren et al., 1995). The base of Zone N12 is placed at the LO of Globorotalia fohsi fohsi (12.7 Ma; Berggren et al., 1995) in Sample 903C$17 \mathrm{R}-3,34-36 \mathrm{~cm}$. Globorotalia fohsi peripheroronda (HO at 14.6 Ma; Berggren et al., 1985c, 1995) persists upwards to Sample 903C$14 \mathrm{R}-\mathrm{CC}$, possibly because of reworking. Samples upward from Core $14 \mathrm{R}$ contain progressively sparser assemblages, most of which contain few taxa and are impossible to date.

\section{Hole $903 A$}

Sample 150-903A-76X-CC at the bottom of Hole 903A contains a planktonic foraminiferal assemblage assignable to the Chronozone N10-N12 interval. Taxa include Globorotalia miozea, G. mayeri, G. fohsi peripheroronda, and Globoquadrina altispira globosa (Fig. 7). Following an interval in which samples are barren or contain sparse, 


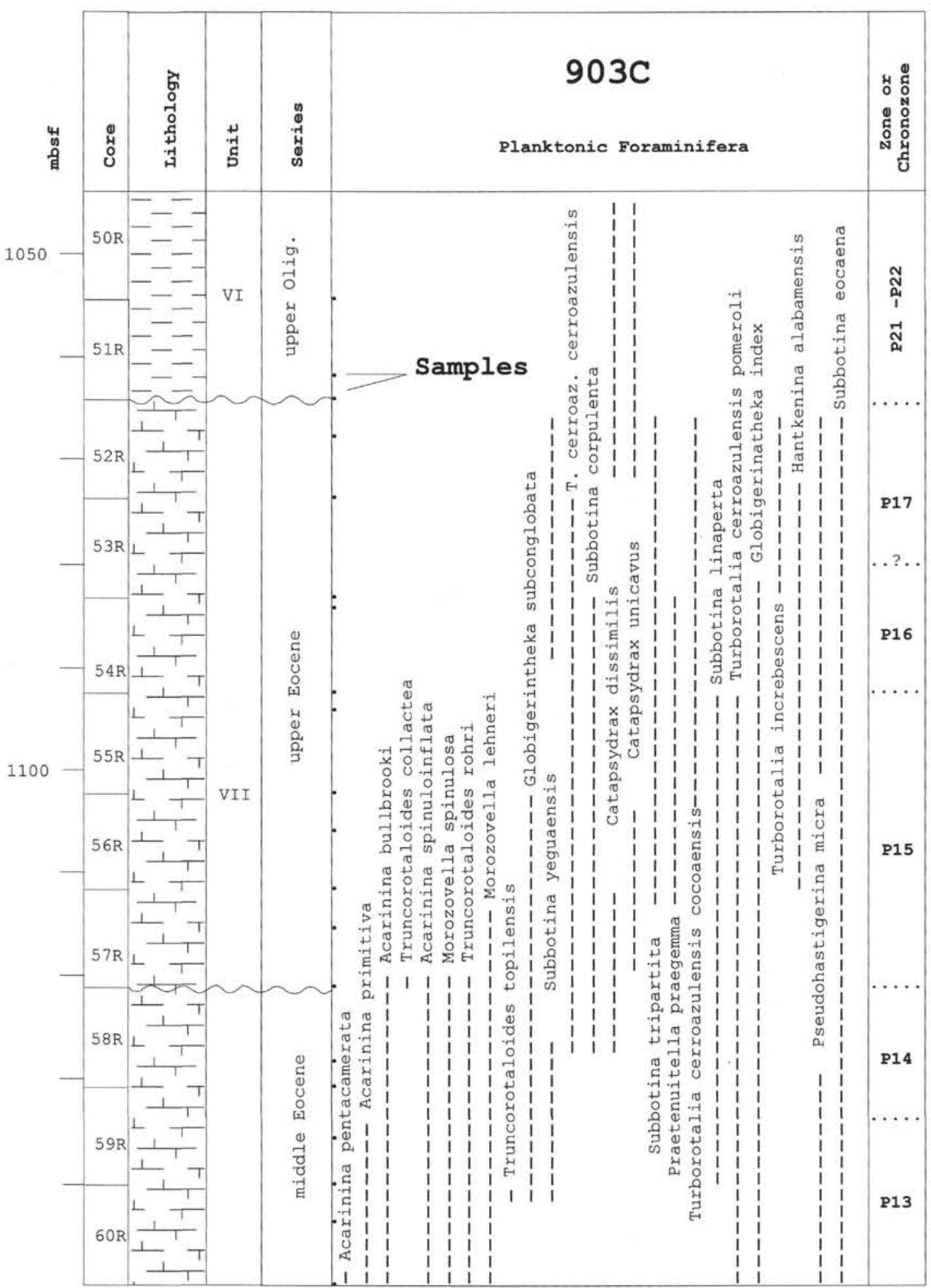

Figure 5. Planktonic foraminiferal biostratigraphy of the Eocene section, Hole 903C. Dashed lines indicate entire stratigraphic range of taxa but do not imply that specimens occur in all samples within that range. 


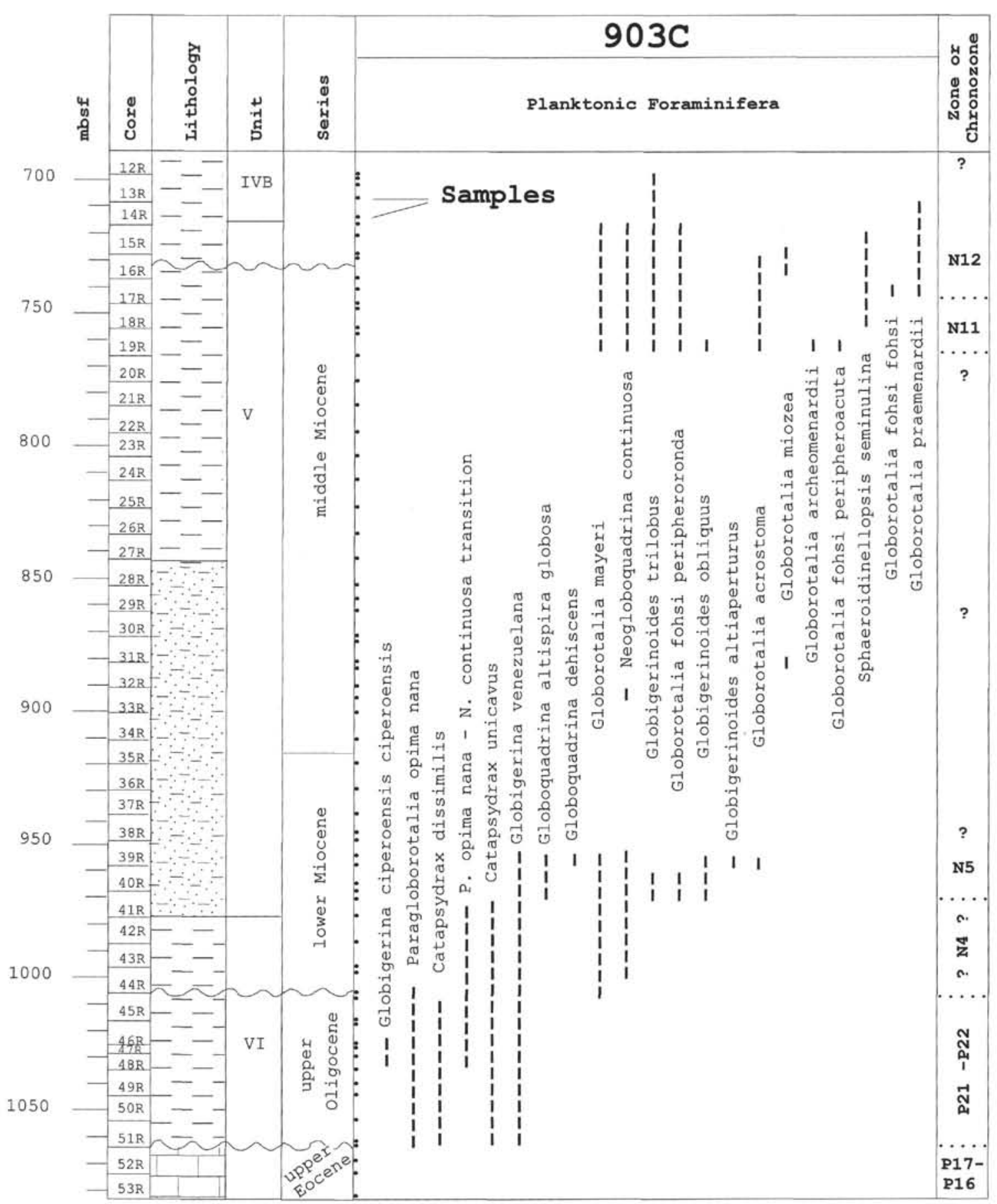

Figure 6. Planktonic foraminiferal biostratigraphy of the Oligocene-Miocene section, Hole 903C. Dashed lines indicate entire stratigraphic range of taxa but do not imply that specimens occur in all samples within that range.

nondiagnostic faunas, the Chronozone N10-N12 interval is encountered again from Sample 150-903A-69X-CC upward through 903A59X-CC, based, in part, on the following taxa: Globorotalia mayeri, G. fohsi peripheroronda, G. praemenardii, and Globoquadrina altispira globosa. Despite a slightly more diverse assemblage, individual zones within in this interval cannot be differentiated.

The sediments immediately overlying Sample 150-903A-59X$\mathrm{CC}$ are barren of planktonic foraminifers. Age-diagnostic assemblag- es are next encountered in Sample 903A-47X-4, 88-90 cm. Here an assemblage containing Globorotalia conoidea, Globorotalia menardii "A," and Neogloboquadrina acostaensis (LO at 10.2 Ma [Berggren et al., 1985c], readjusted to $10.9 \mathrm{Ma}$ [Berggren et al., 1995]) indicates upper Miocene sediments assignable to Zones N16-N17. Neogloboquadrina pachyderma and Globigerina nepenthes (LO at $11.3 \mathrm{Ma}$ [Berggren et al., 1985c], readjusted to $11.8 \mathrm{Ma}$ [Berggren et al., 1995]) join the taxa above in Sample 903A-44X-CC. The LO of 


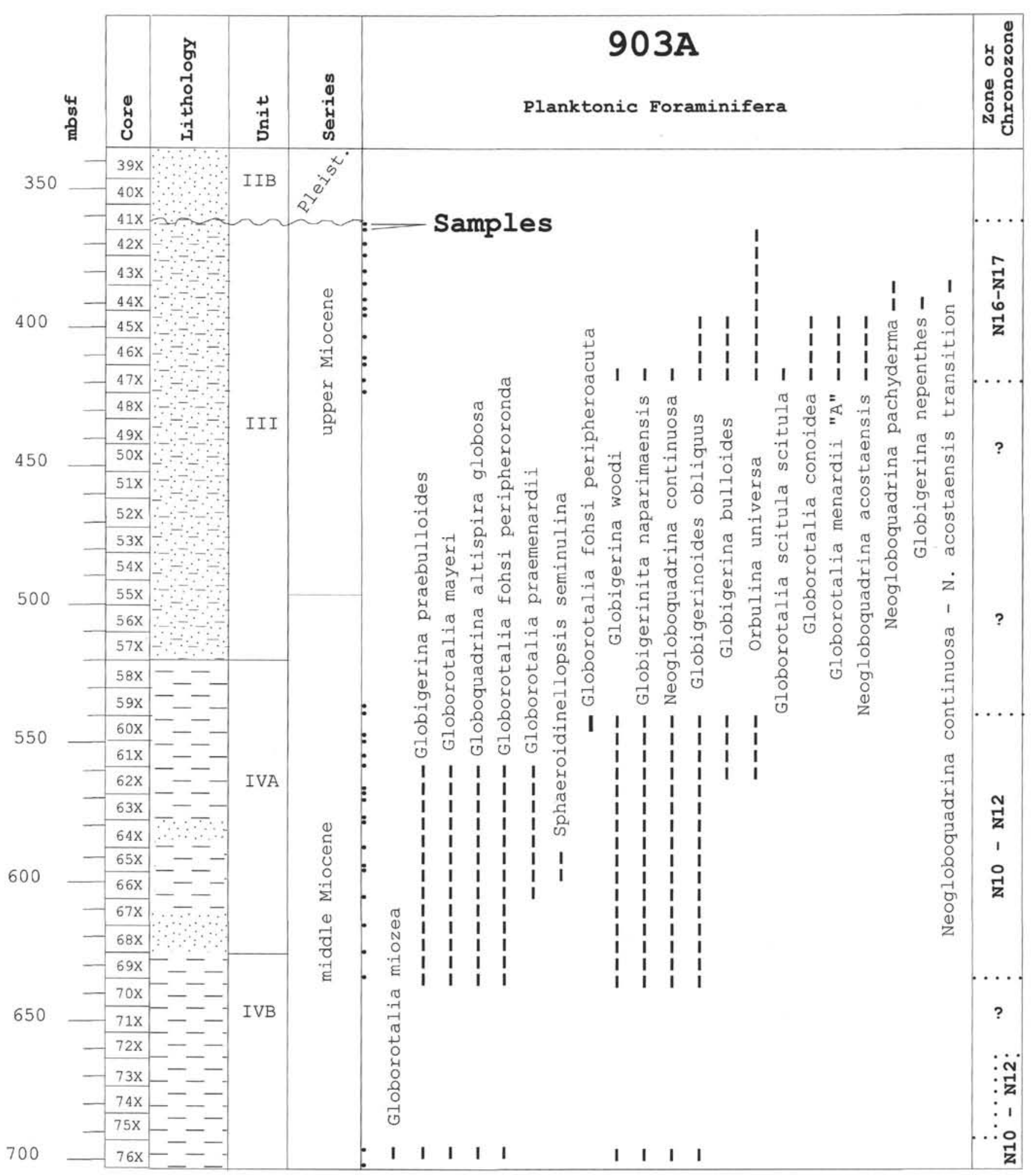

Figure 7. Planktonic foraminiferal biostratigraphy of the Miocene section, Hole 903A. Dashed lines indicate entire stratigraphic range of taxa but do not imply that specimens occur in all samples within that range. 
G. nepenthes here is either delayed, or more likely the product of chance preservation.

\section{SUMMARY}

Within the limitations imposed by diagenetic destruction of $\mathrm{CaCO}_{3}$ and by reworking of specimens representing older taxa into younger sediments, the biostratigraphic framework provided by planktonic foraminifers at Sites 902, 903, and 904 agrees rather well with other interpretations, both of Leg 150 materials and in a broader regional perspective. For example, Oligocene through middle Miocene planktonic foraminiferal biostratigraphy closely parallels $\mathrm{Sr}$ isotope stratigraphy at these sites. Foraminifer-based interpretations cannot revolve some of the unconformities detected by $\mathrm{Sr}$ isotopes, and a few premature highest occurrences and delayed lowest occurrences have been noted, but agreement between the two approaches is generally good (Miller et al., this volume).

Planktonic foraminiferal biostratigraphy of Sites 902-904 presents interesting contrasts and similarities to results from onshore drilling (Miller et al., 1994a, 1994b). Eocene sections from the Island Beach and Atlantic City Beach boreholes are similar to those on the New Jersey slope, whereas Oligocene sections differ. The major lower Oligocene unconformity in slope sites of Leg 150 is not as long onshore, where lower Oligocene Zones P18 and P19 are represented in both boreholes. Lower Oligocene sediments were also reported at DSDP Site 612 (Zone P18) and at ASP 15 (Zones P19/20) (Poag, 1985; Poag and Ward, 1993). The Miocene biostratigraphy from Sites 902-904, although far from complete, contributes biostratigraphic information not recovered in the onshore sections.

From a broader regional perspective, Leg 150 results both corroborate and amplify interpretations from previous studies. For example, the reworking of middle Eocene specimens into upper Eocene sediments as a consequence of disturbances possibly caused by bolide impact may shed more light on the nature and timing of the impact(s). The relationship of the tektite-bearing horizon in Hole 904A to structures such as the Toms Canyon and Chesapeake Bay impact craters (Poag et al., 1992, 1994; Poag and Aubry, 1995) may help to determine how such horizons were emplaced and from where the materials in them were derived. Comparison to the allostratigraphic framework proposed by Poag and Ward (1993) for the U.S. middle Atlantic continental margin indicates that most of their alloformations are represented, at least in part, by the lithostratigraphic units at Sites 902 904. Depositional patterns and unconformities at Sites 902-904 also broadly parallel sea-level fluctuations modeled by Haq et al. (1987), although additional studies will be required before any causal relationships can be suggested.

Despite these similarities to other studies and to patterns of the broader regional stratigraphic framework, the most striking feature of the three sites investigated is how different they are from each other, even though they are so close together. For example, the tektite-bearing horizon at Site 904 has not been recognized at Site 903, even though a siliciclastic layer is present within correlative pelagic carbonate sediments there. Oligocene through early Miocene depositional events and unconformities are similar between Sites 902 and 903 , but contrast markedly with Site 904 . Even the presence or absence of calcareous microfossils varies markedly from site to site. These differences reflect the complex geologic history of this margin and its localized responses to both regional and global phenomena.

\section{ACKNOWLEDGMENTS}

Grants from the U.S. Science Support Program, funded by the National Science Foundation, supported cruise participation and postcruise research. We thank R. Mark Leckie, Al Melillo, and C. Wylie Poag for critical reviews that improved the manuscript.

\section{REFERENCES}

Berggren, W.A., Kent, D.V., and Flynn, J.J., 1985a. Jurassic to Paleogene, Part 2. Paleogene geochronology and chronostratigraphy. In Snelling, N.J. (Ed.), The Chronology of the Geological Record. Geol. Soc. London Mem., 10:141-195.

Berggren, W.A., Kent, D.V., Flynn, J.J., and Van Couvering, J.A., 1985b. Cenozoic geochronology. Geol. Soc. Am. Bull., 96:1407-1418.

Berggren, W.A., Kent, D.V., and Van Couvering, J.A., 1985c. The Neogene, Part 2. Neogene geochronology and chronostratigraphy. In Snelling, N.J. (Ed.), The Chronology of the Geological Record. Geol. Soc. London Mem., 10:211-260.

Berggren, W.A., Kent, D.V., Swisher, C.C., III, and Aubry, M.-P., 1995. A revised Cenozoic geochronology and chronostratigraphy. In Berggren, W.A., Kent, D.V., and Hardenbol, J. (Eds.), Geochronology, Time Scales, and Global Stratigraphic Correlations: A Unified Temporal Framework for an Historical Geology. Spec. Publ.-Soc. Econ. Paleontol. Mineral., 54.

Berggren, W.A., and Miller, K.G., 1988. Paleogene tropical planktonic foraminiferal biostratigraphy and magnetobiochronology. Micropaleontology, 34:362-380.

Blow, W.H., 1969. Late middle Eocene to Recent planktonic foraminiferal biostratigraphy. In Brönnimann, P., and Renz, H.H. (Eds.), Proc. First Int. Conf. Planktonic Microfossils, Geneva, 1967: Leiden (E.J. Brill), 1:199-422.

, 1979. The Cainozoic Globigerinida: Leiden (E.J. Brill)

Bolli, H.M., and Saunders, J.B., 1985. Oligocene to Holocene low latitude planktonic foraminifera. In Bolli, H.M., Saunders, J.B., and PerchNielsen, K. (Eds.), Plankton Stratigraphy: Cambridge (Cambridge Univ. Press), 155-262.

Chaisson, W.P., and Leckie, R.M., 1993. High-resolution Neogene planktonic foraminifer biostratigraphy of Site 806, Ontong Java Plateau (western equatorial Pacific). In Berger, W.H., Kroenke, L.W., Mayer, L.A., et al., Proc. ODP, Sci. Results, 130: College Station, TX (Ocean Drilling Program), 137-178.

Haq, B.U., Hardenbol, J., and Vail, P.R., 1987. Chronology of fluctuating sea levels since the Triassic. Science, 235:1156-1167.

Hodell, D.A., Mueller, P.A., and Garrido, J.R., 1991. Variations in the strontium isotopic composition of seawater during the Neogene. Geology, 19:24-27.

Kennett, J.P., and Srinivasan, M.S., 1983. Neogene Planktonic Foraminifera: A Phylogenetic Atlas: Stroudsburg, PA (Hutchinson Ross).

Leckie, R.M., Farnham, C., and Schmidt, M.G., 1993. Oligocene planktonic foraminifer biostratigraphy of Hole 803D (Ontong Java Plateau) and Hole 628A (Little Bahama Bank), and comparison with the southern high latitudes. In Berger, W.H., Kroenke, L.W., Mayer, L.A., et al., Proc. ODP, Sci. Results, 130: College Station, TX (Ocean Drilling Program), 113-136.

Macleod, N., Keller, G., and Kitchell, J.A., 1990. Prognosis in late Eocene populations of Subbotina linaperta (Foraminifera) from the western Atlantic. Mar. Micropaleontol., 16:219-240.

Miller, K.G., Aubry, M.-P., Khan, K.J., Melillo, A.J., Kent, D.V., and Berggren, W.A., 1985. Oligocene-Miocene biostratigraphy, magnetostratigraphy and isotopic stratigraphy of the western North Atlantic. Geology, $13: 257-261$.

Miller, K.G., Browning, J.V., Liu, C., Sugarman, P., Kent, D.V., Van Fossen, M., Queen, D., Goss, M., Gwynn, D., Mullikin, L., Feigenson, M.D., Aubry, M.-P., and Burckle, L.D., 1994a. Atlantic City site report. In Miller, K.G., et al., Proc. ODP, Init. Repts., 150X: College Station, TX (Ocean Drilling Program), 35-55.

Miller, K.G., Feigenson, M.D., Kent, D.V., and Olsson, R.K., 1988. Upper Eocene to Oligocene isotope $\left({ }^{87} \mathrm{Sr} /{ }^{86} \mathrm{Sr}, \delta^{18} \mathrm{O}, \delta^{13} \mathrm{C}\right)$ standard section, Deep Sea Drilling Project Site 522. Paleoceanography, 3:223-233.

Miller, K.G., Feigenson, M.D., Wright, J.D., and Clement, B.M., 1991. Miocene isotope reference section, Deep Sea Drilling Project Site 608 an evaluation of isotope and biostratigraphic resolution. Paleoceanography, 6:33-52.

Miller, K.G., Mountain, G.S., and Shipboard Scientific Party, 1994. Introduction. In Mountain, G.S., Miller, K.G., Blum, P., et al., Proc. ODP Init. Repts., 150: College Station, TX (Ocean Drilling Program), 5-9.

Miller, K.G., Sugarman, P., Van Fossen, M., Liu, C., Browning, J.V., Queen, D., Aubry, M.-P., Burckle, L.D., Goss, M. and Bukry, D., 1994b. Island Beach site report. In Miller, K.G., et al., Proc. ODP, Init. Repts., 150X College Station, TX (Ocean Drilling Program), 5-33. 
Miller, K.G., Wright, J.D., and Brower, A.N., 1989. Oligocene to Miocene stable isotope stratigraphy and planktonic foraminifer biostratigraphy of the Sierra Leone Rise (DSDP Site 366 and ODP Site 667). In Ruddiman, W., Sarnthein, M., et al., Proc. ODP, Sci. Results, 108: College Station, TX (Ocean Drilling Program), 279-294.

Oslick, J.S., Miller, K.G., and Feigenson, M.D., 1994. Oligocene-Miocene strontium isotopes: stratigraphic revisions and correlations to an inferred glacioeustatic record. Paleoceanography, 9:427-443.

Poag, C.W., 1985. Depositional history and stratigraphic reference section for central Baltimore Canyon trough. In Poag, C.W. (Ed.), Geologic Evolution of the United States Atlantic Margin: New York (Van Nostrand Reinhold), 217-263.

Poag, C.W., and Aubry, M.-P., 1995. Upper Eocene impactites of the U.S. coast: depositional origins, biostratigraphic framework, and correlation. Palaios, 10:16-43.

Poag, C.W., and Low, D., 1987. Unconformable sequence boundaries at Deep Sea Drilling Project Site 612, New Jersey Transect: their characteristics and stratigraphic significance. In Poag, C.W., Watts, A.B., et al., Init. Repts. DSDP, 95: Washington (U.S. Govt. Printing Office), 453500

Poag, C.W., Powars, D.S., Poppe, L.J., and Mixon, R.B., 1994. Meteroid mayhem in ole Virginny: source of the North American tektite strewn field. Geology, 22:691-694.

Poag, C.W., Powars, D.S., Poppe, L.J., Mixon, R.B., Edwards, L.E., Folger, D.W., and Bruce, S., 1992. Deep Sea Drilling Project Site 612 bolide event: new evidence of a late Eocene impact-wave deposit and a possible impact site, U.S. east coast. Geology, 20:771-774.
Poag, C.W., and Ward, L.W., 1993. Allostratigraphy of the U.S. middle Atlantic continental margin - characteristics, distribution, and depositional history of principal unconformity-bounded Upper Cretaceous and Cenozoic sedimentary units. Geol. Surv. Prof. Pap. U.S., 1542:1-81.

Shipboard Scientific Party, 1994a. Site 905. In Mountain, G.S., Miller, K.G., Blum, P., et al., Proc. ODP, Init. Repts., 150: College Station, TX (Ocean Drilling Program), 255-308.

1994b. Site 906. In Mountain, G.S., Miller, K.G., Blum, P., et al., Proc. ODP, Init. Repts., 150: College Station, TX (Ocean Drilling Program), 309-357.

Stainforth, R.M., Lamb, J.L., Luterbacher, H., Beard, J.H., and Jeffords, R.M., 1975. Cenozoic planktonic foraminiferal zonation and characteristics of index forms. Univ. Kans. Paleontol. Contrib., Article, 62:1-425.

Toumarkine, M., and Luterbacher, H., 1985. Paleocene and Eocene planktic foraminifera. In Bolli, H.M., Saunders, J.B., and Perch-Nielsen, K. (Eds.), Plankton Stratigraphy: Cambridge (Cambridge Univ. Press), 87154.

Zhang, J., Miller, K.G., and Berggren, W.A., 1993. Neogene planktonic foraminiferal biostratigraphy of the northeastern Gulf of Mexico. Micropaleontology, 39:299-326.

Date of initial receipt: 28 February 1995

Date of acceptance: 26 July 1995

Ms 150SR-001 